\title{
PENERAPAN LAYANAN ARSIP PERATURAN PEMERINTAH SEBAGAI ARSIP DINAMIS INAKTIF BERDASARKAN KLASIFIKASI KEAMANAN DAN AKSES ARSIP DI KEMENTERIAN SEKRETARIAT NEGARA REPUBLIK INDONESIA
}

\author{
Dewi Rahmawati \\ Mahkamah Konstitusi Republik Indonesia \\ dewirawa@gmail.com
}

\begin{abstract}
The systematic records process of Peraturan Pemerintah is also balanced with the application of security classification and records access. This classification is to protect the information and physical records from damage and lose so that the records are available, easy to read, intact, authentic, trustworthy, and save. There are three methods used in writing this final report. Participation observation that was done by joining in process of records managing in Ministry of State Secretary of Indonesia from processing to records service in Bagian Arsip. Interview that was done by asking and answering to records managers who manage and give the records service in Ministry of State Secretary of Indonesia. The third is literature review which is used as reference and to collect the data in writing this final project.

The records services of Peraturan Pemerintah in Kementrian Sekretariat Negara Republik Indonesia has been appropriate to the security classification and records access. However, there is less coordination between Bagian Arsip, PPID, and Asisten Deputi Hukum on providing clarity in charge of records service of the original draft file.
\end{abstract}

Key words: Records services, government regulation records, inactive records, security classification, access

\section{Intisari}

Pengolahan arsip Peraturan Pemerintah secara sistematis diimbangi dengan penerapan klasifikasi keamanan dan akses arsip. Klasifikasi ini bertujuan untuk melindungi fisik dan informasi arsip dari kerusakan dan kehilangan agar dapat tetap tersedia, mudah dibaca, utuh, otentik, andal serta terjaga keamanannya. Terdapat tiga metode yang digunakan dalam penyusunan tugas akhir ini. Observasi partisipasi yang dilakukan dengan turut serta langsung dalam proses pengelolaan arsip di Kementerian Sekretariat Negara Republik Indonesia dari pengolahan sampai layanan arsip di Bagian Arsip. Wawancara yang dilakukan dengan tanya jawab kepada arsiparis yang mengelola dan memberikan layanan arsip di Kementerian Sekretariat Negara Republik Indonesia. Studi pustaka yang digunakan sebagai referensi dan pengumpulan data dalam penulisan tugas akhir.

Layanan arsip Peraturan Pemerintah di Kementerian Sekretariat Negara Republik Indonesia sudah berdasarkan pada klasifikasi keamanan dan akses arsip. Namun terdapat kendala yang menghambat yaitu kurangnya koordinasi antara Bagian Arsip, PPID, dan Asisten Deputi Hukum dalam memberikan kejelasan penanggungjawab layanan arsip berkas naskah asli.

Kata kunci: Layanan arsip, arsip peraturan pemerintah, arsip dinamis inaktif, klasifikasi keamanan, akses 


\section{PENDAHULUAN}

Kementerian Sekretariat Negara Republik Indonesia merupakan lembaga pemerintah yang dipimpin oleh Sekretaris Negara, berkedudukan di bawah dan bertanggungjawab kepada Presiden. Kementerian Sekretariat Negara Republik Indonesia bertugas menyelenggarakan dukungan teknis dan administrasi serta analisis urusan pemerintahan di bidang kesekretariatan negara untuk membantu Presiden dan Wakil Presiden dalam menyelenggarakan kekuasaan negara. Kementerian Sekretariat Negara Republik Indonesia disebut sebagai satuan organisasi atau wadah dalam penyelenggaraan kegiatan penunjang presiden. Menteri Sekretaris Negara dalam hal ini sebagai sekretaris pimpinan tertinggi yaitu presiden. Tugas yang diemban oleh Menteri Sekretaris Negara beserta jajarannya disebut dengan kesekretariatan negara. Kesekretariatan negara merupakan segala bentuk kegiatan penunjang untuk mencapai tujuan atau visi misi yang hendak dicapai oleh Kementerian Sekretariat Negara Republik Indonesia.

Salah satu misi Kementerian Sekretariat Negara Republik Indonesia adalah menyelenggarakan pelayanan yang efektif dan efisien di bidang pengawasan, administrasi umum, informasi dan hubungan kelembagaan. Bidang-bidang tersebut termasuk ke dalam pelayanan publik. Misi Kementerian Sekretariat Negara Republik Indonesia dengan mengedepankan efektivitas dan efisiensi di bidang pengawasan, administrasi umum, informasi, dan hubungan kelembagaan tersebut merupakan rangkaian kegiatan dalam rangka pemenuhan kebutuhan pelayanan jasa dan administratif. Salah satu pemenuhan pelayanan jasa dan administratif tersebut adalah pelayanan informasi. Informasi memiliki peran penting dan strategis untuk menjawab permasalahan pelayanan publik dan perubahan dinamika masyarakat yang serba cepat. Pemberian pelayanan informasi dapat dikatakan sebagai pemenuhan kebutuhan masyarakat akan informasi.

Kementerian Sekretariat Negara Republik Indonesia menyediakan pelayanan informasi kepada publik atau sering disebut dengan memberikan pelayanan informasi publik. Pelayanan ini dapat diakses oleh publik melalui Pejabat Pengelola Informasi dan Dokumentasi di Kemeterian Sekretariat Negara. Pejabat Pengelola Informasi dan Dokumentasi adalah pejabat yang bertanggung jawab di bidang penyimpanan, pendokumentasian, penyediaan, dan/ atau pelayanan informasi di Badan Publik (Mulyadi, 2016). Dalam melaksanakan tugas dan tanggungjawabnya, Pejabat Pengelola Informasi dan Dokumentasi di Kementerian Sekretariat Negara Republik Indonesia mempunyai standar pelayanan tersendiri. Standar pelayanan merupakan suatu komitmen penyelenggara pelayanan untuk menyediakan pelayanan dengan suatu kualitas tertentu yang ditentukan atas dasar perpaduan harapan -harapan masyarakat dan kemampuan penyelenggara pelayanan (Mulyadi, 2016). Standar pelayanan ini dijadikan sebagai tolok ukur dan pedoman dalam memberikan pelayanan informasi.

Pejabat Pengelola Informasi dan Dokumentasi dalam memberikan pelayanan informasi tidak berdiri sendiri. Bagian Arsip Biro Tata Usaha merupakan penyedia arsip yang dibutuhkan oleh publik melalui Pejabat Pengelola Informasi dan Dokumentasi. Bagian Arsip sendiri juga bekerjasama dengan unit pencipta arsip yang memindahkan arsip yang dimiliki yang sudah menjadi inaktif. Salah satu unit kerja tersebut adalah Asisten Deputi Hukum yang menyerahkan arsip peraturan perundang -undangannya ke Bagian Arsip. Asisten Deputi Hukum sebagai unit pencipta arsip peraturan perundang-undangan mempunyai salah satu series arsip yang 
tergolong sering diakses masyarakat dalam bentuk salinan yang diunggah ke website, internal Kementerian Sekretariat Negara Republik Indonesia, maupun badan peradilan yang membutuhkan. Series arsip tersebut adalah arsip Peraturan Pemerintah. Peraturan Pemerintah merupakan merupakan peraturan yang diterbitkan untuk memberikan penjelasan terhadap undang-undang agar tidak terjadi kesalah tafsiran bagi masing-masing penafsir kebijakan. Hal tersebut berarti bahwa arsip Peraturan Pemerintah tercipta setelah adanya Undang-Undang mengenai aturan tertentu agar tidak terjadi salah tafsir atau sebagai peraturan penjelas dari Undang-Undang.

Arsip Peraturan Pemerintah ini dalam pelayanannya diatur dengan adanya klasifikasi keamanan dan akses arsip. Aturan ini terdapat dalam Peraturan Menteri Sekretaris Negara nomor 2 tahun 2016 tentang Petunjuk Pelaksanaan Klasifikasi Keamanan Dan Akses Arsip Di Kementerian Sekretariat Negara. Definisi petunjuk pelaksanaan klasifikasi keamanan dan akses arsip yaitu pedoman bagi pejabat/ pegawai terkait dalam menyediakan layanan informasi arsip kepada pihakpihak yang berkepentingan baik secara internal maupun eksternal/ publik dengan prinsip cepat, tepat, terotorisasi, dan aman. Definisi tersebut menjelaskan bahwa pihak-pihak yang berkepentingan terkait dengan penyediaan layanan informasi arsip harus mengikuti pedoman tersebut. Pihak -pihak yang dimaksud yaitu Pejabat Pengelola Informasi dan Dokumentasi sebagai penyedia layanan informasi publik, Bagian Arsip sebagai penyedia layanan arsip internal, dan unit pencipta dalam hal ini adalah Asisten Deputi Hukum.

Arsip Peraturan Pemerintah yang sudah diserahkan, dikelola, dan disimpan di Bagian Arsip merupakan salah satu arsip inaktif tekstual. Arsip inaktif merupakan arsip yang frekuensi penggunaannya telah menurun (Sugiarto dan Wahyono, 2015). Arsip yang telah menurun frekuensinya tersebut harus diserahkan ke Bagian Arsip sebagai pusat arsip. Records center atau pusat arsip didirikan untuk mengelola dan menyimpan arsip inaktif. The centers are used to fulfill two major needs: to serve as low cost storage centers for inactive records and to serve as reference service center (Ricks, 1992). Pusat yang digunakan untuk memenuhi dua kebutuhan besar: untuk menyediakan pusat penyimpanan untuk arsip inaktif dengan biaya rendah dan menyediakan pusat layanan referensi. Hal ini berarti bahwa records center selain sebagai tempat penyimpanan arsip inaktif dengan biaya rendah juga menyediakan pusat layanan referensi bagi pengguna.

Berdasarkan latar belakang tersebut, penulis merumuskan permasalahan sebagai berikut:

1. Bagaimana pengolahan arsip inaktif yang mendukung adanya layanan arsip di Kementerian Sekretariat Negara Republik Indonesia?

2. Bagaimana prosedur layanan arsip baik secara internal maupun eksternal di Kementerian Sekretariat Negara Republik Indonesia?

3. Bagaimana penerapan klasifikasi keamanan dan akses arsip Peraturan Pemerintah dalam lingkup internal maupun eksternal Kementerian Sekretariat Negara Republik Indonesia?

4. Apa kendala dalam memberikan layanan arsip Peraturan Pemerintah dalam lingkup internal dan eksternal Kementerian Sekretariat Negara Republik Indonesia

\section{Metode Pengumpulan Data}

Dalam pengumpulan data, peneliti menggunakan 3 (tiga) metode, yaitu 
observasi partisipasi, wawancara terstruktur, dan kajian pustaka. Peneliti mengobservasi prosedur layanan arsip dinamis inaktif dan penerapan pedoman klasifikasi keamanan dan akses arsip. Wawancara terstruktur dilakukan dengan mewawancarai arsiparis Kementerian Sekretariat Negara RI.

\section{Pengelolaan Arsip di Kementerian Sekretariat Negara Republik Indonesia}

Kementerian Sekretariat Negara Republik Indonesia sebagai lembaga pemerintah yang bertanggungjawab kepada Presiden dan Wakil Presiden membuat arsip yang tercipta di lingkungan Kementerian Sekretariat Negara Republik Indonesia mempunyai berbagai jenis atau series arsip. Berbagai jenis arsip di Kementerian Sekretariat Negara Republik Indonesia dalam bentuk ataupun media yang bermacam-macam jenis pula. Media tersebut yaitu tekstual dan dalam bentuk khusus. Bentuk tekstual adalah arsip yang medianya berupa kertas. Kertas dalam hal ini merupakan media untuk merekam kegiatan dengan menggunakan tinta yang digoreskan ke kertas tersebut. Selain itu juga terdapat bentuk khusus seperti arsip audiovisual (sound recording, still image, moving image), mini DV, mikrofilm.

Mikrofilm merupakan kebijakan di Bagian Arsip Kementerian Sekretariat Negara Republik Indonesia bahwasanya arsip yang sebelum diserahkan ke Arsip Nasional Republik Indonesia harus sudah dialih mediakan dengan mikrofilm karena berfungsi sebagai back up arsip. Hal ini dilakukan karena pimpinan, pegawai, maupun masyarakat masih mencari arsip yang sudah diserahkan ke Arsip Nasional Republik Indonesia. Khusus untuk masyarakat untuk autentikasinya harus datang ke Arsip Nasional Republik Indonesia karena sudah arsip yang sudah diserahkan ke ANRI sudah menjadi wewenang ANRI untuk memberikan legalisasi dan unit pencipta arsip tidak dapat memberikan legalisasi kepada masyarakat dengan mudah karena untuk menghindari ancaman maupun resiko yang akan muncul. Bagian Arsip menganggap mikrofilm sampai saat ini masih menjadi teknologi yang paling sesuai untuk penyimpanan arsip-arsip yang bernilai kesejarahan dan arsip vital yang dimiliki oleh Kementerian Sekretariat Negara Republik Indonesia.

Arsip inaktif di Bagian Arsip berasal dari berbagai unit kerja di lingkungan Kementerian Sekretariat Negara Republik Indonesia. Arsip inaktif tersebut disimpan dalam mobile file. Terdapat 24 mobile file di ruang penyimpanan arsip inaktif di Bagian Arsip. Mobile file tersebut terdiri dari mobile file $\mathrm{A}$ sampai $\mathrm{X}$ yang terpisah menjadi dua ruang penyimpanan. Mobile file A sampai dengan mobile file $\mathrm{Q}$ terdapat di ruang penyimpanan arsip I dan dari mobile file $\mathrm{R}$ sampai dengan mobile file $\mathrm{X}$ terdapat di ruang penyimpanan arsip II. Mobile file $\mathrm{F}$ sampai dengan $\mathrm{Q}$ berisi masing-masing 12 roll, Mobile file $\mathrm{R}$ sampai dengan $\mathrm{U}$ masing-masing 10 roll, dan mobile file $\mathrm{V}$ sampai dengan $\mathrm{X}$ masing-masing 12 roll. Setiap roll dari mobile file A sampai mobile file E terdiri dari 9 shelf sehingga mobile file A-E terdiri dari 250 shelf. Setiap shelf berisi 10 boks arsip yang berukuran kecil sehingga jumlah boks dari mobile file A-E adalah 2500 boks. Untuk mobile file $\mathrm{F}$ sampai dengan $\mathrm{Q}$, setiap rollnya terdiri dari 10 shelf sehingga mobile file $\mathrm{F}$ sampai dengan $\mathrm{Q}$ terdiri dari 1440 shelf. Setiap shelf berisi 10 boks arsip yang berukuran kecil sehingga jumlah boks dari mobile file $\mathrm{F}$ sampai Q adalah 14.400 boks. Dari mobile file $\mathrm{R}$ sampai dengan mobile file $\mathrm{U}$, setiap rollnya terdiri dari 5 shelf sehingga mobile file $\mathrm{R}$ sampai dengan mobile file $\mathrm{U}$ terdiri dari 200 shelf. Setiap shelf berisi 10 boks arsip yang berukuran kecil sehingga jumlah boksnya yaitu 2000 boks. Untuk mobile file $\mathrm{V}$ sampai dengan $\mathrm{X}$, setiap rollnya terdiri dari 10 shelf 
sehingga mobile file $\mathrm{V}$ sampai dengan mobile file $\mathrm{X}$ terdiri dari 360 shelf. Setiap shelf berisi 10 boks arsip yang berukuran kecil sehingga jumlah boks dari mobile file V sampai X adalah 3600 boks. Jadi, total keseluruhan boks arsip adalah 22.000 boks. Dari data tersebut dapat diketahui jumlah volume yang terdapat di ruang penyimpanan arsip yaitu 2.250 ML. Pada kenyataannya, beberapa kali arsiparis Bagian Arsip menemukan daftar arsip pindah tidak sinkron dengan fisik arsipnya, Bagian arsip juga masih menyimpan arsip yang sering dikatakan "arsip tak bertuan". Pernyataan tersebut berarti bahwa arsip tersebut tidak jelas siapa penciptanya karana adanya perubahan nomenklatur dan tidak adanya unit yang mengakui kepemilikan arsip tersebut.

Unit kerja yang menyerahkan daftar arsip dalam membuat klasifikasi arsip masih terdapat kesalahan dalam memberikan kode klasifikasi. Beberapa unit kearsipan menyerahkan daftar pemindahan arsip dengan klasifikasi dalam bentuk primer dan/atau sekundernya saja. Pengklasifikasian tersebut masih sangat umum. Hal ini menyebabkan adanya proses pengolahan arsip ulang oleh arsiparis Bagian Arsip. Selain itu dalam penyimpanan arsip dalam bentuk media khusus maupun tekstual belum ada cross reference atau petunjuk silang. Arsip yang disimpan masih diklasifikasikan sendiri-sendiri sesuai dengan jenis medianya. Arsip yang mempunyai satu jalan cerita tetapi mempunyai jenis media yang berbeda haruslah jelas letak penyimpanan berkas pendukungnya atau arsip audiovisualnya, dan lain sebagainya. Dilihat dari segi keamanan fisik arsip yang disimpan di Bagian Arsip, masih terdapat beberapa arsip dalam bentuk berlubang maupun disteples. Kondisi ini muncul sejak arsip tersebut berada di unit penciptanya. Steples tersebut membuat arsip berlubang dan arsiparis harus menghilangkannya agar mempermudah dalam alih media serta menghilangkan steples yang semakin berkarat. Selain itu arsip yang dipindahkan ke Bagian Arsip juga masih terdapat beberapa unit kearsipan menyerahkan dalam boks plastik yang bersifat panas dan dapat membuat fisik arsip lengket dengan boks. Hal ini menyebabkan beberapa arsip yang sudah ada di mobile Gile masih terdapat arsip yang disimpan dengan menggunakan boks plastik.

\section{Penerapan Layanan Arsip Peraturan Pemerintah Berdasarkan Klasifikasi Keamanan dan Akses Arsip}

Layanan arsip di Kementerian Sekretariat Negara Republik Indonesia terdapat di Bagian Arsip, Biro Tata Usaha. Layanan ini dinamakan dengan peminjaman arsip. Peminjaman arsip dilakukan oleh pegawai di setiap unit kerja yang membutuhkan arsip. Pegawai yang datang ke Bagian Arsip untuk meminjam arsip mempunyai berbagai kepetingan dalam penggunaan arsip yang diciptakan oleh unit pencipta. Kepentingan tersebut seperti menjadikan arsip sebagai acuan untuk melaksanakan suatu kegiatan, digunakan sebagai bahan pertimbangan, dan lain-lain sesuai dengan kepentingan masing-masing pegawai.

Selain layanan arsip, Kementerian Sekretariat Negara Republik Indonesia juga menyediakan layanan informasi publik. Suatu informasi tentu berasal dari arsip. Layanan informasi publik dilaksanakan Pejabat Pengelola Informasi dan Dokumentasi di bawah naungan Asisten Deputi Hubungan Kemasyarakatan. Pihak yang dapat mendapatkan layanan informasi publik yaitu pihak eksternal Kementerian Sekretariat Negara seperti masyarakat, lembaga, badan peradilan, dan lain-lain. Untuk mendapatkan layanan informasi publik mauun layanan peminjaman arsip di Kementerian Sekretariat Negara Republik Indonesia terdapat beberapa 
prosedur yang harus dilalui oleh pengguna. Prosedur- prosedur tersebut tentunya harus diimbangi dengan adanya syarat yang berlaku untuk pengguna, dan sarana prasarana penunjang adanya layanan arsip. Komponen-komponen tersebut diantaranya:

1. Prosedur Pelayanan Peminjaman Arsip di Bagian Arsip:

a. Staf Bagian Arsip menerima dan mencatat memorandum permohonan peminjaman arsip inaktif dari satuan organisasi/ unit kerja di lingkungan Kementerian Sekretariat Negara Republik Indonesia yang telah mendapat arahan dari Kepala Biro Tata Usaha kemudian menyampaikannya kepada Kepala Bagian Arsip (2 menit)

b. Kepala Bagian menugaskan Kepala Subbagian Inventarisasi dan Pengolahan untuk menindaklanjuti arahan Kepala Biro Tata Usaha (5 menit)

c. Kepala Subbagian Inventarisasi dan Pengolahan melakukan penelitian terhadap memorandum/surat

permohonan peminjaman arsip dengan arsip yang ada untuk: arsip inaktif (5 menit) dan arsip vital dan penting (15 menit)

d. Kepala Subbagian Inventarisasi dan Pengolahan menugaskan arsiparis/ staf pada Bagian Arsip untuk melakukan penemuan kembali (pencarian) arsip yang dipinjam (3 menit).

e. Arsiparis/staf Bagian Arsip melakukan penemuan kembali arsip yang akan dipinjam (5 menit)

f. Arsiparis/staf Bagian Arsip melakukan penggandaan dokumen/arsip yang dipinjam (3-10 menit).

g. Arsiparis melakukan pengisian dan penandatangan lembar peminjaman arsip yang tersedia dan meminta tanda tangan peminjam (2 menit).

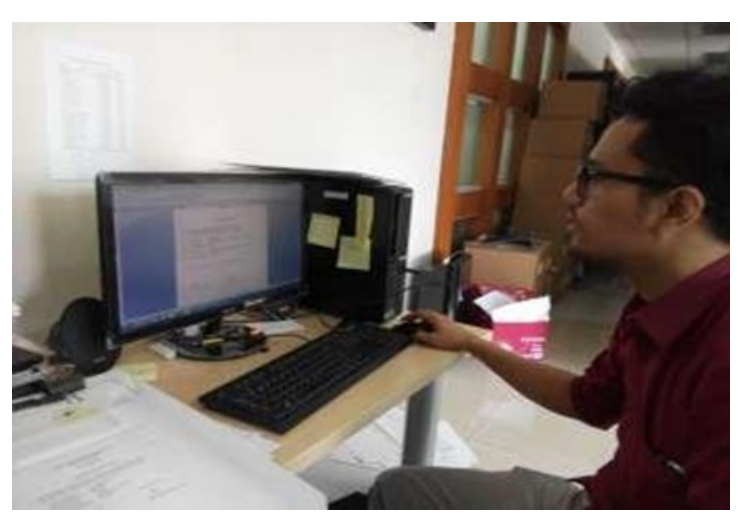

Gambar 1. Petugas membuat lembar peminjaman arsip (koleksi pribadi)

2. Persyaratan Pelaksana Pelayanan di Bagian Arsip

a. Adanya permohonan peminjaman arsip dari satuan organisasi/unit kerja di lingkungan Kementerian Sekretariat Negara Republik Indonesia, instansi Pemerintah, dan masyarakat

b. Adanya arahan dari pimpinan

c. Memiliki kompetensi sesuai dengan jenjang masing-masing. Kompetensi yang dimaksud adalah kompetensi profesional dan kompetensi teknis. Kompetensi profesional merupakan kemampuan dalam penguasaan teori kearsipan secara luas dan mendalam (Rokhmatun, 2013). Selain kompetensi profesional, arsiparis harus memiliki kompetensi teknis. Kompetensi teknis adalah kemampuan dalam mengelola penyelenggaraan kearsipan (Rokhmatun, 2013).

3. Persyaratan Administratif/Teknis Bagi Pengguna Pelayanan di Bagian Arsip, Mengajukan permohonan peminjaman arsip kepada Kepala Biro Tata Usaha

4. Sarana dan Prasarana Pelayanan di Bagian Arsip: Sarana penemuan kembali arsip (daftar arsip dan 
kode klasifikasi arsip), lembar peminjaman arsip, alat tulis kantor, masker, mesin foto kopi, komputer, printer dan scanner

\section{Pelayanan Informasi Publik Melalui Penanganan Permohonan}

1. Tim Sekretariat PPID menerima permohonan informasi publik baik secara tertulis maupun tidak tertulis dari pengguna pelayanan (pemohon)

a. Apabila permohonan diajukan secara tidak tertulis, maka akan dilakukan tahap pemeriksaan

b. Apabila permohonan diajukan secara tidak tertulis, maka Tim Sekretariat PPID mencatat permohonan pada formulir yang tersedia (30 menit)

2. Tim Sekretariat PPID memeriksa kejelasan permohonan informasi dan validitas identitas pemohon (15 menit).

a. Apabila data valid, maka akan dilakukan tahap pencatatan

b. Apabila data tidak valid (permohonan informasi dan/ atau identitas pemohon tidak jelas), maka Tim Sekretariat PPID akan menghubungi pemohon untuk konfirmasi agar memperjelas permohonan dan/ atau melengkapi data serta mengirim kembali kelengkapannya

3. Tim Sekretariat PPID melakukan pencatatan permohonan informasi pada register permohonan informasi publik (15 menit)

4. Tim Sekretariat PPID menyerahkan nomor pendaftaran kepada pemohon informasi sebagai tanda bukti permohonan (5 menit):

a. Apabila pemohon datang langsung atau melalui surat elektronik, maka nomor pendaftaran diberikan pada saat permohonan diterima

b. Apabila tidak dapat diberikan secara langsung, nomor pendaftaran dapat dikirim bersamaan dengan jawaban permohonan kepada pemohon informasi

5. Tim Sekretariat PPID mengajukan lembaran permohonan informasi publik kepada Ketua PPID melalui Sekretaris PPID (5 menit):

a. Ketua PPID menelaah permohonan informasi publik dan memberikan arahan kepada Anggota PPID terkait untuk menindaklanjutinya ( 1 jam).

b. Ketua PPID memeriksa dan menandatangani

pemberitahuan tertulis/ jawaban dan Surat Keputusan PPID tentang Penolakan Permohonan Informasi

6. Tim Sekretariat PPID menyampaikan pemberitahuan tertulis/ jawaban beserta Surat Keputusan PPID tentang Penolakan Permohonan Informasi baik secara langsung maupun melalui kantor pos atau email (10 menit). Penjelasan mengenai prosedur tersebut digunakan untuk permohonan informasi selain produk hukum atau peraturan Perundang-undangan. Salinan Peraturan Perundang-undangan yang telah diotentifikasi khususnya Peraturan Pemerintah sudah tersedia di website. Pengguna yang sudah tahu akan adanya website dapat mengunduh Peraturan Pemerintah yang diinginkan dan mencetaknya. Namun pemohon yang tidak tahu adanya website yang sudah tersedia beberapa produk hukum di dalamnya masih terdapat yang datang langsung, mengirim formulir melalui pos maupun email. Hal tersebut tetap dilayani oleh staff PPID dengan cara mencetakkan Peraturan Pemerintah yang dikehendaki oleh pemohon 
tetapi tetap menyerahkan atau mengirimkan formulir dan kartu identitas sebagai bukti permohonan.

\section{Klasifikasi Keamanan dan Akses Arsip Peraturan Pemerintah}

Klasifikasi keamanan dan akses arsip di Kementerian Sekretariat Negara Republik Indonesia tertuang dalam peraturan Menteri Sekretaris Negara nomor 2 tahun 2016. Peraturan ini diciptakan oleh Bagian Arsip sebagai pusat arsip atau unit kearsipan I dan Biro Organisasi, Tata Laksana, dan Akuntabilitas Kinerja. Arsiparis di Bagian Arsip sebagai perancang Klasifikasi dan Keamanan Akses Arsip yang disesuaikan

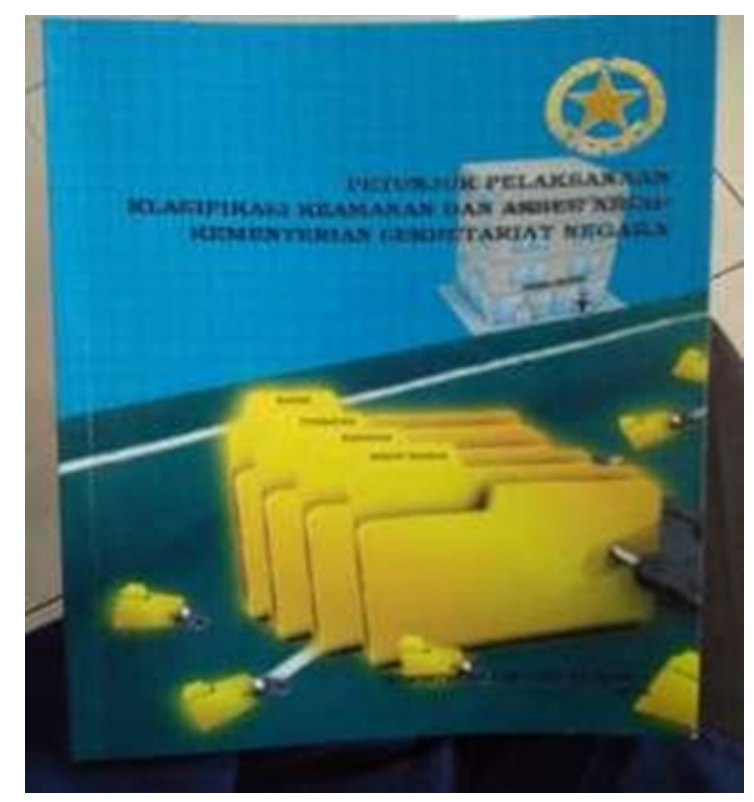

Gambar 2. Buku petunjuk pelaksanaan klasifikasi keamanan dan akses arsip (koleksi pribadi)

dengan UU nomor 43 tahun 2009 tentang Kearsipan dan mengacu pada Peraturan Kepala Arsip Nasional Republik Indonesia Nomor 17 Tahun 2011 Tentang Pedoman Pembuatan Sistem Klasifikasi Keamanan Dan Akses Arsip Dinamis.

Klasifikasi keamanan adalah kategori kerahasiaan informasi arsip berdasarkan pada tingkat keseriusan dampak yang akan ditimbulkannya terhadap kepentingan dan keamanan negara, masyarakat, dan perorangan. Klasifikasi akses arsip adalah kategori pembatasan akses berdasarkan kewenangan penggunaan arsip terkait dengan pelaksanaan fungsi tertentu. Kedua pengertian tersebut dipadukan menjadi klasifikasi keamanan dan akses arsip yang berarti kategori informasi arsip berdasarkan dampak yang akan ditimbulkan dan pembatasan akses kewenangan penggunaan arsip terkait dengan pelaksanaan fungsi tertentu. Klasifikasi keamanan dan akses arsip bertujuan untuk menjaga suatu arsip dari resiko yang mengancam arsip dan mempermudah adanya proses layanan baik untuk internal Kementerian Sekretariat Negara Republik Indonesia dan publik/ eksternal Kementerian Sekretariat Negara Republik Indonesia. Layanan yang baik tentunya harus meninjau dari klasifikasi keamanan dan akses arsipnya. Klasifikasi biasa dan terbatas masih bisa diakses oleh publik tetapi untuk rahasia dan sangat rahasia sangatlah sulit untuk mendapatkan arsip ataupun informasi yang dicari. Klasifikasi keamanan dan akses arsip menurut Permensesneg nomor 2 tahun 2016 terdapat 4 klasifikasi, yaitu biasa, terbatas, rahasia, dan sangat rahasia. Klasifikasi biasa merupakan arsip yang memiliki informasi yang apabila diketahui oleh orang banyak, tidak merugikan siapapun.

Arsip terbatas merupakan arsip yang memiliki informasi apabila diketahui oleh pihak-pihak yang tidak berhak dapat mengakibatkan terganggunya pelaksanaan tugas dan fungsi lembaga pemerintahan. Arsip terbatas ini sering dinilai sama dengan klasifikasi biasa. Namun kenyataannya klasifikasi ini lebih beresiko daripada arsip atau berkas yang mempunyai klasifikasi biasa. Arsip rahasia adalah arsip yang memiliki informasi apabila diketahui oleh pihak yang tidak berhak dapat mengakibatkan terganggunya 
fungsi penyelenggaraan negara, sumber daya nasional dan/ atau ketertiban umum. Arsip sangat rahasia adalah arsip yang memiliki informasi yang apabila diketahui oleh pihak yang tidak berhak dapat membahayakan kedaulatan negara, keutuhan wilayah Negara Kesatuan Republik Indonesia, dan/ atau keselamatan bangsa. Arsip peraturan pemerintah diciptakan oleh Asisten Deputi Hukum, Deputi Bidang Hukum dan Perundang-undangan. Pada pembuatan Klasifikasi peraturan perundang-undangan khususnya arsip peraturan pemerintah, bagian arsip telah memberikan formulir untuk diisikan yang berisi arsip-arsip yang diciptakan berserta klasifikasi keamanan dan akses arsip oleh Deputi Bidang yang bersangkutan. Setelah formulir diisi Bagian Arsip menuangkannya ke dalam peraturan klasifikasai keamanan dan akses arsip, begitu juga sama dengan unit kerja lainnya.

Deputi Bidang Hukum dan Perundang-undangan memindahkan arsip Peraturan Pemerintah yang telah memasuki masa inaktif ke Bagian Arsip. Sebagai pencipta arsip, Deputi Hukum dan Perundang-undangan mempunyai hak penuh terhadap kepemilikan arsip yang dipindahkan di Bagian Arsip. Tempat dimana arsip Peraturan Pemerintah memang sudah berpindah tetapi kepemilikan dan kewenangan terhadap arsip peraturan pemerintah masih berada di tangan Deputi Bidang Hukum dan Perundang-undangan. Arsip peraturan pemerintah mempunyai 2 berkas yang disimpan oleh Bagian Arsip yang berasal dari Deputi Hukum dan Perundang-undangan sebagai unit pencipta, diantaranya berkas naskah asli dan berkas pendukung. Berkas naskah asli berisi penetapan Presiden; Peraturan Pemerintah yang telah ditetapkan; dan otentikasi. Selain berkas asli, terdapat pula berkas pendukung. Berkas pendukung berisi pengajuan pemrakarsa; hasil harmonisasi dari Kementerian
Hukum dan HAM kepada pemrakarsa; hasil analisis; tindak lanjut pendapat hukum, dan telaah staf; hasil rakor pemantauan, dan pelaporan; evaluasi dan pendapat hukum atas RPP; perubahan RPP dan perubahan PP. Berikut ini klasifikasi keamanan berkas arsip Peraturan Pemerintah:

Adanya klasifikasi keamanan tersebut timbul batasan-batasan pengakses arsip atau disebut dengan hak akses. Hak akses merupakan pihak-pihak yang dizinkan atau mempunyai hak untuk mengakses arsip peraturan pemerintah. Hak akses dan identifikasi pengguna arsip Peraturan Pemerintah yaitu:

a. Biasa

1) Penentu kebijakan

2) Pelaksana kebijakan

3) Pengawas

4) Pengelola arsip

5) Penegak hukum

6) Publik

b. Terbatas

1) Penentu kebijakan

2) Pelaksana kebijakan

3) Pengawas

4) Penegak hukum

c. Rahasia

1) Penentu kebijakan

2) Pengawas

3) Penegak hukum

d. sangat rahasia

1) Penentu kebijakan

2) Pengawas

3) Penegak hukum

Arsip Pengajuan dari pemrakarsa dan arsip Hasil haromonisasi dari Kementerian Hukum dan HAM kepada pemrakarsa diklasifikasikan terbatas karena arsip terebut masih berupa pengajuan dari si pemangku kebijakan yang mengajukan untuk membuat suatu peraturan pemerintah dan hasil penyelarasan dari Kementerian Hukum dan HAM kepada pemrakarsa. Klasifikasi terbatas tersebut menunjukan bahwa yang berhak mengakses yaitu penentu 
kebijakan, pelaksana kebijakan, pengawas, dan penegak hukum. Arsip yang mempunyai klasifikasi keamanan rahasia yaitu hasil analisis, tindak lanjut pendapat hukum dan telaah staf, hasil rakor pemantauan dan pelaporan, evaluasi dan pendapat hukum atas RPP, Perubahan RPP dan perubahan PP, Penetapan Presiden, dan PP yang telah ditetapkan. Adanya klasifikasi tersebut menandakan bahwa yang berhak mengakses arsip-arsip tersebut yaitu penentu kebijakan, pengawas, dan penegak hukum. Hal ini berbeda dengan arsip peraturan pemerintah yang telah melewati tahap otentifikasi yang mempunyai klasfikasi biasa. Pihak-pihak yang berhak mengakses arsip tersebut yaitu Penentu kebijakan, Pelaksana kebijakan, Pengawas, Pengelola arsip, Penegak hukum, dan Publik.

Hak akses arsip yang sudah diotentifikasi juga diberikan untuk publik. tahun 2011 tentang Pembentukan Peraturan Perundang-Undangan Bagian ketiga mengenai Naskah yang Disebarluaskan pasal 95 yang berbunyi: "Naskah Peraturan Perundang-undangan yang disebarluaskan harus merupakan salinan naskah yang telah diundangkan dalam Lembaran Negara Republik Indonesia, Tambahan Lembaran Negara Republik Indonesia, Berita Negara Republik Indonesia, Tambahan Berita Negara Republik Indonesia, Lembaran Daerah, Tambahan Lembaran Daerah, dan Berita Daerah". Bunyi pasal tersebut menjelaskan bahwa naskah peraturan perundang- undangan yang disebarluaskan berupa lembaran negara, berita negara, dan lain sebagainya yang sudah diundangkan dan diberi otentifikasi pada lembar pengesahan suatu peraturan perundang-undangan. Namun bentuk redaksi tersebut harus berupa salinan arsipnya saja. Adanya hak akses yang dibuktikan dengan bunyi pasal tersebut menandakan bahwa berkas pendukung berupa naskah rancangan Peraturan Pemerintah, perubahan Peraturan Pemerintah, hasil analisis tidak dapat disebarluaskan dan mempunyai klasifikasi rahasia.

\section{Penerapan Klasifikasi Keamanan Dan Akses Arsip melalui Peminjaman Arsip Peraturan Pemerintah (manual) di Bagian Arsip (internal)}

Penerapan Peraturan Menteri Sekretaris Negara nomor 2 tahun 2016 menganai Petunjuk Pelaksanaan Klasifikasi Keamanan dan Akses Arsip telah dilaksanakan oleh Bagian Arsip sebagai pembuat kebijakan. Tidak dapat dipungkiri dalam pembuatan peraturan tersebut, Bagian Arsip tetap mengikutsertakan pencipta arsip dengan cara membagikan kuesioner atau formulir untuk diisikan arsip yang tercipta di bidang masing-masing, klasifikasi keamanannya beserta klasifikasinya dalam hal ini adalah Bidang Distribusi, Publikasi, dan Dokumentasi yang berada di bawah Asisten Deputi Hukum. Bagian Arsip pun tetap berpedoman terhadap peraturan yang telah dibuat bersama dengan seluruh unit pencipta arsip di lingkungan Kementerian Sekretariat Negara Republik Indonesia.

Saat pemilik arsip membutuhkan arsip ke Bagian Arsip, arsiparis mengizinkan orang yang bersangkutan untuk masuk ke dalam ruang penyimpanan. Hal itu terjadi karena arsiparis Bagian Arsip merasa pemilik arsip berwenang untuk masuk ke ruang penyimpanan arsipyang mereka miliki. Pemilik arsip pun menyadari bahwa tetap menjaga arsip yang dimiliki dan menjaga keamanan arsip tersebut karena memasuki ruang penyimpanan yang tidak hanya menyimpan arsip Peraturan Pemerintah saja. Kedua belah pihak merasa saling memiliki dan menjaga keamanan dari arsip yang berada di Bagian Arsip. Bagian arsip dalam memberikan layanan peminjaman arsipnya sudah menggunakan klasfikasi 
keamanan dan akses arsip tetapi perlu adanya evaluasi dalam pelaksanaan layanan tersebut. Evaluasi layanan peminjaman arsip dapat dilakukan dengan cara menghitung rasio penggunaan dan rasio akurasi penemuan kembali (Place, 1992):

Rasio Penggunaan:

$\frac{\text { Jumlah Arsip Yang Diminta }}{\text { Jumlah Arsip Yang Tersedia }}=\frac{3 \text { Arsip }}{323 \text { Box }}=0,021 \%$

Arsip peraturan Pemerintah yang dipinjam oleh bidang Distribusi, Publikasi, dan Dokumentasi terdapat 7 arsip Peraturan Pemerintah yang dipinjam setiap tahunnya. Jumlah tersebut sangat sedikit dibanding dengan Arsip Peraturan Pemerintah yang berjumlah 323 boks di Bagian Arsip. Hasil dari rasio penggunaan berasal dari jumlah arsip yang diminta setiap tahunnya adalah 7 arsip Peraturan Pemerintah dibagi dengan jumlah arsip Peraturan Pemerintah yang tersedia di Bagian Arsip dengan jumlah 323 boks. Berdasarkan hasil persentase 0,021\% tersebut menyatakan bahwa penggunaan atau peminjaman arsip Peraturan Pemerintah terbilang rendah. Rasio penggunaan yang rendah berarti bahwa arsip dengan nilai yang rendah diciptakan dan dirawat atau prosedur pemberkasannya tidak efektif. Namun hasil persentase tersebut berbeda dengan pernyataan salah seorang arsiparis yang menjadi koordinator layanan peminjaman arsip yang menyatakan bahwa arsip Peraturan Pemerintah penggunaannya tergolong sedang karena arsip Undang-Undang lebih tinggi daripada arsip Peraturan Pemerintah dan masih ada peraturan perundangan yang penggunaannya lebih rendah daripada arsip Peraturan Pemerintah.

Selain rasio penggunaan, terdapat pula rasio akurasi penemuan kembali. Penghitungan ini berguna mengetahui keakuratan dalam proses penemuan kembali suatu arsip. Penghitungannya sebagai berikut (Place, 1992):

Rasio akurasi penemuan kembali :

$\frac{\text { Jumlah Arsip Yang Ditemukan }}{\text { Jumlah Arsip Yang Diminta }}=\frac{10 \text { berkas }}{2 \text { berkas }} \times 10=50 \%$

Rumus asli pada penghitungan rasio akurasi penemuan kembali ini sebenarnya tidak dikali dengan angka 10. Hal ini dikarenakan arsip yang ditemukan dalam 1 boksnya terdapat 10 berkas yang dapat ditemukan apabila membuka boks. Berbeda dengan jumlah arsip yang diminta oleh bidang Distribusi, Publikasi, dan Dokumentasi, rata-rata hanya 2 berkas saja. Jumlah arsip yang ditemukan oleh arsiparis Bagian Arsip rata-rata terdapat 10 berkas dalam 1 boks dan dibagi dengan arsip yang diminta yaitu 2 berkas arsip. Hasil dari pembagian itu adalah 50\%. Hasil ini tergolong cukup baik akurasi penemuan kembali karena 100\% merupakan angka yang paling akurat untuk penemuan kembali (Place, 1992).

Arsip Peraturan Pemerintah biasa dipinjam untuk beberapa kepetingan. Kepentingan tersebut diantaranya sebagai bahan kajian, pertimbangan revisi/ perubahan Peraturan Pemerintah. Pihak yang berkepentingan tentunya merupakan pihak yang mendapatkan hak akses sesuai dengan klasifikasi keamanan dan akses arsip. Kepentingan tersebut mengharuskan untuk meminjam naskah yang ditanda tangani basah atau naskah asli yang disimpan di dalam kertas casing dan prosedurnya melalui PPID terlebih dahulu lalu diarahkan ke Asisten Deputi Hukum jika arsip tersebut masih berada di Asisten Deputi Hukum dapat dilayankan. Hal itu berbeda jika sudah dipindahkan di Bagian Arsip maka Asisten Deputi Hukum meminjamkan terlebih dahulu ke Bagian Arsip. PPID juga dapat langsung menghubungi Bagian Arsip apabila sudah mengetahui arsip 
yang dibutuhkan sudah dipindahkan ke Bagian Arsip.

\section{Penerapan Klasifikasi Keamanan Dan Akses Arsip melalui Layanan Salinan Arsip Peraturan Pemerintah (website) di Pejabat Pengelola Informasi dan Dokumentasi (eksternal)}

Seiring perkembangan zaman, majunya teknologi informasi, dan tuntutan adanya e-government, menu di website Kementerian Sekretariat Negara Republik Indonesia telah berbasis pelayanan publik khususnya layanan informasi publik yang menyediakan layanan arsip berupa salinan. Pelayanan arsip berupa salinan maupun layanan informasi publik di Kementerian Sekretariat Negara Republik Indonesia sudah lebih maju. Hal itu dapat dilihat dari ketersediaan arsip berupa salinan yang terdapat dalam website setneg.go.id terdapat salinan peraturan perundangundangan pada bagian produk hukum. Pengguna dapat mengunduhnya kapan pun dan dimana pun. Terdapat kekurangan dari website ini, kekurangan tersebut terletak pada jumlah pengunguh arsip atau informasi yang tersedia di website tidak terlihat dan tidak dapat mengetahui grafik pelayanan informasi publik.

Penerapan website sebagai media untuk memberikan layanan arsip berupa salinan ini diselenggarakan oleh PPID yang bekerjasama dengan Biro Informasi Dan Teknologi, serta Bidang Distribusi, Publikasi, dan Dokumentasi yang berada di bawah Asisten Deputi Hukum. Tidak hanya salinan arsip maupun informasi yang tersedia di website tetapi dengan website pula pengguna dapat mengunduh formulir peminjaman arsip. Formulir ini dapat diunduh melalui website setneg.go.id, dicetak, dan dikirm melalui pos, datang langsung, maupun email. Hal ini akan sangat memudahkan bagi pengguna website yang akan memohon informasi publik atau meminjam arsip untuk keperluan tertentu di Kementerian
Sekretariat Negara Republik Indonesia.

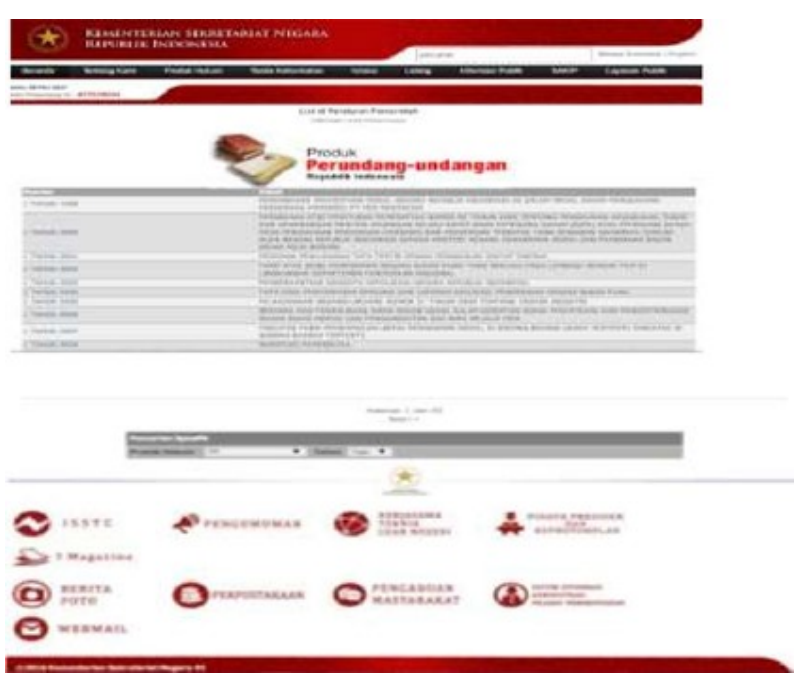

Gambar 3. Daftar Peraturan Pemerintah yang dapat diunduh dalam bentuk Pdf. (koleksi pribadi)

Peraturan perundang-undangan termasuk Peraturan Pemerintah yang tersedia di website dalam bentuk PDF. Adanya bentuk PDF tersebut mengamankan salinan arsip Peraturan Pemerintah agar tidak dapat diubah oleh siapapun. Namun yang masih disayangkan adalah bentuk PDF tersebut masih dapat disalin oleh pengguna. Pemohon informasi dapat menyatakan keberatan kepada PPID Kementerian Sekretariat Negara Republik Indonesia jika permohonannya tidak ditanggapi oleh PPID. Surat pernyataan tersebut harus mempunyai dasar atau bukti bahwa surat yang dikirim sebelumnya tidak mendapat tanggapan. Surat pernyataan keberatan tersebut dapat diunduh melalui website setneg.go.id tab informasi publik dan pilih formulir. Formulir tersebut dapat diberikan secara langsung ke PPID, pos, maupun email dengan catatan, harus melampirkan surat yang telah dikirim sebelumnya. Adanya kemudahan dalam penyampaian surat pernyataan keberatan ini memudahkan bagi publik yang ingin menyampaikan keberatannya tidak hanya datang langsung melainkan PPID Kementerian Sekretariat Negara Republik Indonesia 
memberikan pilihan lain untuk efektivitas dan efisiensi waktu.

Kendala dalam penerapkan klasifikasi keamanan dan akses arsip pada arsip Peraturan Pemerintah yaitu terletak pada kurangnya koordinasi antara Bagian Arsip, unit kerja, dan PPID dalam memberikan layanan arsip berkas naskah asli peraturan pemerintah kepada pihak-pihak yang berkepentingan. Selain itu, dari ketiga pihak tersebut belum sepenuhnya staff di dalamnya mengetahui tentang adanya Petunjuk Klasifikasi Keamanan di Kementerian Sekretariat Negara Republik Indonesia. Hal itu terjadi karena Peraturan Menteri Sekretaris Negara nomor 2 tahun 2016 terbilang masih baru dan belum disosialisasikan secara mendalam.

\section{KESIMPULAN}

Prosedur layanan arsip Peraturan Pemerintah berdasarkan standar pelayanan peminjaman arsip dan pemberian informasi publik masih terlihat birokratis karena banyaknya alur prosedur melalui berbagai pihak terlebih dahulu dan dapat dibuktikan dengan rasio penggunaan yang rendah yaitu 0,021 \%. Pejabat Pengelola Informasi dan Dokumentasi yang mengklasifikasikan informasi dibuka dan dikecualikan dapat sedikit menyelaraskan dengan adanya petunjuk klasifikasi keamanan yang mengkategorikan arsip dibagi menjadi biasa, terbatas, rahasia, dan sangat rahasia melalui pembagian formulir arsip yang dikecualikan disesuaikan dengan permensesneg nomor 2 tahun 2016 ke unit kerja. Bagian arsip sebelum memberikan layanan peminjaman arsip juga berdasar pada Permensesneg nomor 2 tahun 2016.

Kendala dalam penerapkan klasifikasi keamanan dan akses arsip pada arsip Peraturan Pemerintah yaitu kurangnya koordinasi antara Bagian Arsip, unit kerja, dan PPID dalam memberikan layanan arsip berkas naskah asli peraturan pemerintah kepada pihak- pihak yang berkepentingan. Prosedur dalam peminjaman arsip maupun pemberian informasi publik haruslah lebih efektif dan efisien sehingga pengguna dapat mengakses arsip dengan mudah, cepat, dan tepat.

\section{DAFTAR PUSTAKA}

Betty R. Ricks (1992). Information and Image Management: A Records System Approach, 7d Edition. Ohio: South-Western Publishing.

Moelong, Lexy J. (2016). Metodologi Penelitian Kualitatif. Bandung: Rosda.

Mulyadi, Deddy(2016). Studi Kebijakan Publik dan Pelayanan Publik: Konsep dan Aplikasi Proses Kebijakan Publik Berbasis Analisis Bukti untuk Pelayanan Publik. Bandung: Alfabeta.

Rokhmatun, Burhanudin Dwi (2013). Profesi Kearsipan: Memahami Profesi Kearsipan, Karakteristik \& Syarat, Ketrampilan \& Pengetahuan, Kompetensi, dan Kode Etik Arsiparis. Yogyakarta: Panduan.

Sugiarto, Agus dan Teguh Wahyono (2015). Manajemen Kearsipan Modern: Dari Konvensional ke Basis Komputer. Yogyakarta: Gava Media.

$\begin{array}{ccr}\text { Sukandarrumidi } & \text { (2008). } & \text { Dasar-dasar } \\ \text { Penulisan } & \text { Proposal } & \text { Penelitian. } \\ \text { Yogyakarta: } & \text { Gadjah } & \text { Mada } \\ \text { University Press. } & \end{array}$

